\title{
VARIANT ANATOMY OF INTERNAL THORACIC ARTERY- CLINICAL IMPLICATIONS
}

\author{
Delmotra P ${ }^{* 1}$, Goel $A^{2}$, Singla RK ${ }^{3}$.
}

${ }^{* 1}$ Professor, Department of Anatomy, Adesh Medical college \& Hospital, Mohri, Shahabad(M), Kurukshetra, India.

${ }^{2}$ Associate Professor, Department of Anatomy, Adesh Medical college \& Hospital, Mohri, Shahabad (M), Kurukshetra, India.

${ }^{3}$ Professor, Department of Anatomy, Govt. Medical college, Patiala, India.

\section{ABSTRACT}

Background: Now a days, Internal thoracic artery (ItA) is being widely used in coronary artery bypass grafting $(\mathrm{CABG})$ and in breast reconstructive surgeries. In addition, the area around its origin is also used for subclavian vein catheterization and introducing a pacemaker.

Aim: Aim of the study was to know the normal and variant anatomy of internal thoracic artery in Indian subjects in order to provide useful data to thoracic surgeons, so as to prevent iatrogenic complications in ItA dissections. Clinical applications related to variations were analysed.

Material and Methods: 30 cadavers were dissected to see the mode of origin of internal thoracic artery, diameter at its origin and relation with phrenic nerve and thyrocervical trunk.

Results: 55 arteries were showing normal origin and tend to arise opposite the root of thyrocervical trunk. Remaining 5 were arising in common with one or two branches of thyrocervical trunk. Average diameter at its origin was $2.8 \mathrm{~cm}$ on left and $2.6 \mathrm{~cm}$ on right. Relation with phrenic nerve was variable.

Conclusion: During CABG surgery, Breast reconstructive surgery and various interventional procedures, it is important to know the variant pattern of ItA so as to avoid iatrogenic complications

KEY WORDS: Internal thoracic artery, Thyrocervical trunk, Coronory artery bypass graft, Subclavian artery.

Address for Correspondence: Dr. Delmotra P, Professor, Deptt. of Anatomy, Adesh Medical college \& Hospital, Mohri, Shahabad (M), Kurukshetra, India. Contact no. 9779115489

E-Mail: drpoonamdel@yahoo.co.in

Access this Article online

Quick Response code

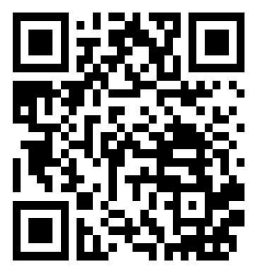

DOI: $10.16965 /$ ijar.2019.136

Journal Information

International Journal of Anatomy and Research

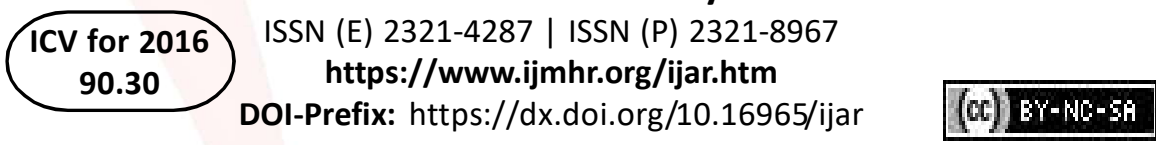

Article Information

Received: 05 Feb 2019

Peer Review: 06 Feb 2019

Revised: None
Accepted: 13 Mar 2019

Published (O): 05 May 2019

Published (P): 05 May 2019

\section{INTRODUCTION}

According to standard textbooks of anatomy, Internal thoracic artery (ITA) arises inferiorly from first part of subclavian artery (SA) about 2 $\mathrm{cm}$ above the sternal end of clavicle, opposite the root of thyrocervical trunk (TT) and near the medial edge of scalenus anterior muscle. It descends in aninward and slightly forward direction to enter the thorax behind the

cartilage of $1^{\text {st }}$ rib [1,2].

Anomalous origin of the ITA has already been reported in the literature. Daseler and Anson encountered an absence of internal thoracic artery in 2 of their 400 specimens. However they are silent about the source of blood supply to the affected area in these [3]. An anomalous origin of this artery from thyrocervical trunk was 
found in $9 \%$ of dissections by Anson [4]. Anomalous unilateral $[5,6]$ or bilateral [7] ItA origin from the third portion of the SCA has also been encountered in the literature in less than $1 \%$ of the cases $[3,6,8]$. They further emphasized the importance of such a variant as the area coursed by it is commonly used for percutaneous subclavian vein catheterization to determine CVP or to administer drugs and solutions in emergency or even to introduce a pacemaker [6].

In recent years, Internal thoracic artery is being widely used for CABG. It has gained importance in CABG because of long term patency $[9,10]$ and survival rate $[11,12]$ and improvement in post-operative quality of life [13], when compared with the results of saphenous vein grafts. Secondly, because of its adequate size and intrathoracic course it is also used as recipient vessels in breast reconstruction [14].

\section{MATERIALS AND METHODS}

30 cadavers were dissected to study the variant anatomy of internal thoracic artery. Deep dissection was done in the region of root of neck to expose the subclavian artery and its branches. Origin of internal thoracic artery was traced. Various parameters were studied in relation to internal thoracic artery. Mode of origin, Diameter at its origin and relation with phrenic nerve and thyrocervical trunk.

\section{RESULTS}

Parent artery: In the present study, internal thoracic artery originated directly from first part of subclavian artery in 55 dissections (91.7\%), 27 on left side (90\%) and 28 on right side (93.3\%). In rest of the 5 sides, it was a variant origin in common with one or the other branch of thyrocervical trunk.(Fig. 1, 2 \&3). On left side anomalous origin was seen in $10 \%$ and right side in 6.7\%. Details are shown in Table 1.

Diameter at origin: Average diameter of internal thoracic artery at its origin was found to be $2.6 \mathrm{~mm}$ (range $1.5-4.0 \mathrm{~mm}$ ) on left side and $2.8 \mathrm{~mm}$ (range $1.9-4.0 \mathrm{~mm}$ ) on right side.

Relation with thyrocervical trunk: Usually the internal thoracic artery tend to group with thyrocervical trunk in 55 disscetions. In present study, 5 internal thoracic arteries were showingits origin with one or two branches of thyrocervical trunk.

Relation with phrenic nerve: Phrenic nerve lies in a close relationship to ItA. It crosses ItA obliquely from lateral to medial side. It was passing anteriorly in 65\% and posteriorly in 35\% on right side and $70 \%$ anterior and $30 \%$ posterior to ITA on left side.

Table 1: Comparison of site and mode of origin of internal thoracic artery.

\begin{tabular}{|c|c|c|c|c|c|c|c|c|c|c|c|}
\hline \multirow[b]{4}{*}{ Sr.No. } & \multirow[b]{4}{*}{ Author (year) } & \multicolumn{9}{|c|}{ Site and mode of origin } & \\
\hline & & \multicolumn{9}{|c|}{ Subclavian artery } & \\
\hline & & \multicolumn{3}{|c|}{ Directly } & \multicolumn{6}{|c|}{ In common with other arteries } & \\
\hline & & 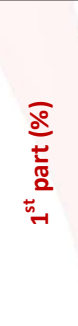 & 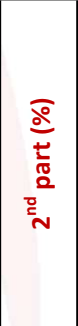 & 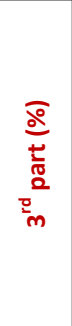 & 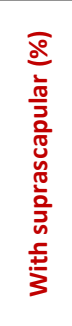 & 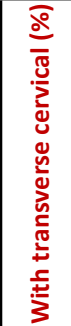 & 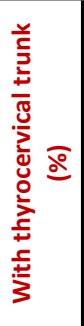 & 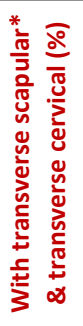 & 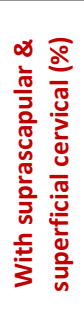 & 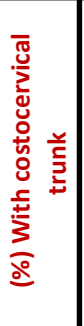 & 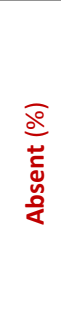 \\
\hline 1 & Quain (1844) [17] & 93.5 & 0.3 & 2 & 1.2 & - & 5 & 1.5 & - & - & - \\
\hline 2 & Bean (1905) [18] & 80 & - & - & 8 & - & 9.7 & 0.77 & - & - & - \\
\hline 3 & DeGaris (1924) [19] & 86.7 & - & 0.72 & 1.1 & - & 2.5 & 1.1 & - & - & - \\
\hline 4 & Daseler and Anson (1959) [3] & 79.19 & 3.64 & 0.78 & 3.77 & 0.78 & 8.84 & 0.28 & - & - & 0.28 \\
\hline 5 & Krechowiecki et al (1973) [8] & - & - & 0.5 & - & - & - & - & - & - & - \\
\hline 6 & Henriquez-Pino et al (1997) [13] & 82.5 & & & 9.5 & & & 3.5 & & - & \\
\hline 7 & Vorster et al (1998) [6] & - & - & 0.83 & - & - & - & - & - & - & - \\
\hline 8 & Karaman et al(2012) [20] & 99.1 & & & & & 0.3 & & & 0.6 & \\
\hline 9 & Present study (2013) & 91.7 & - & - & 1.67 & - & - & 3.3 & 3.3 & - & - \\
\hline
\end{tabular}

* According to International Anatomical Nomenclature committee, transverse scapular artery has been renamed as suprascapular (Huelke, 1958), however since in earlier studies this name exists so mentioned here, otherwise it should be read as suprascapular artery. [21] 
Fig. 1: Left subclavian artery (LSA) giving a common trunk of origin (CT) for internal thoracic (ItA) and suprascapular (SS) while inferior thyroid artery (ITA) emanates directly from it [TG- Thyroid gland ; PN- Phrenic nerve].

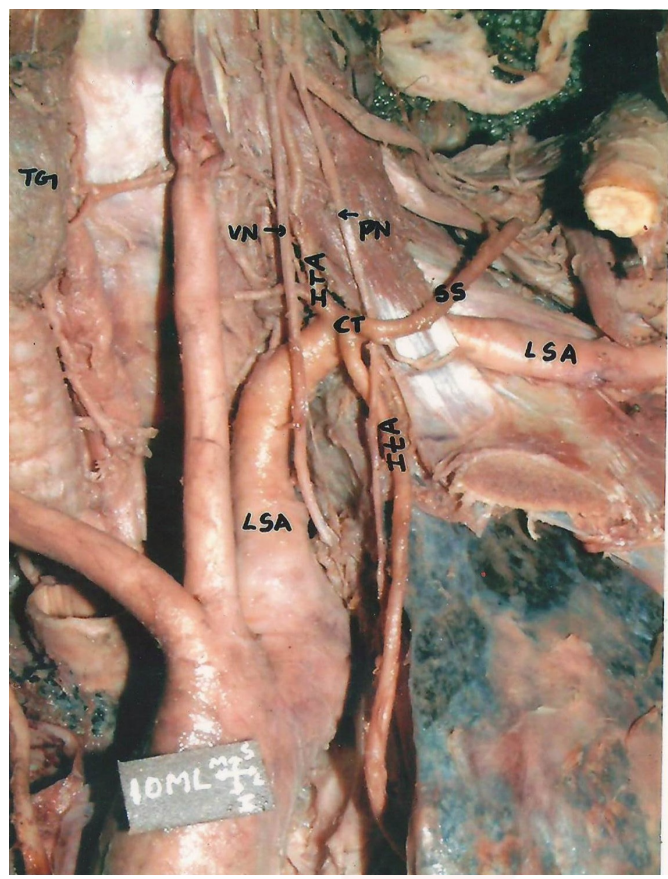

Fig. 2: A common trunk for Internal thoracic artery(ItA), Suprascapular (SS) and transverse cervical (TC) arising from left subclavian artery.

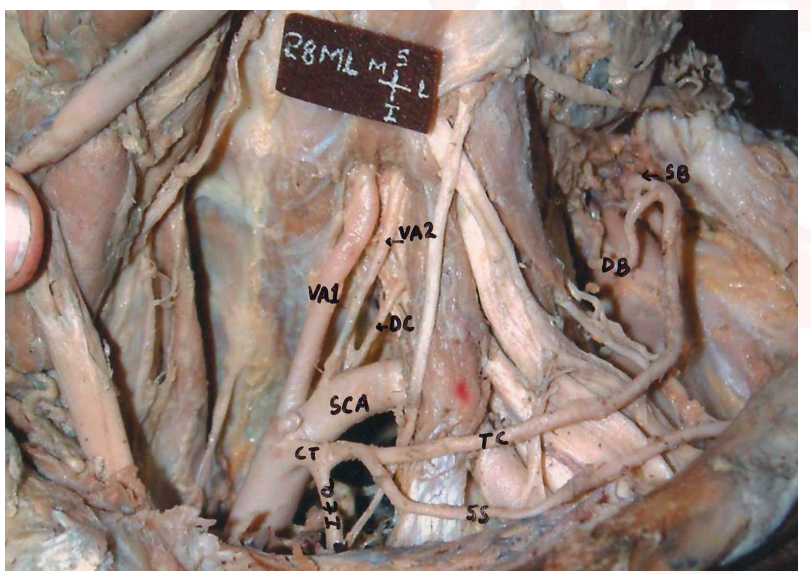

Fig. 3: A common trunk for Internal thoracic artery(ItA), Suprascapular (SS) and transverse cervical (TC) arising from right subclavian artery. Inferior throid artery (ITA) arising separately from subclavian artery.

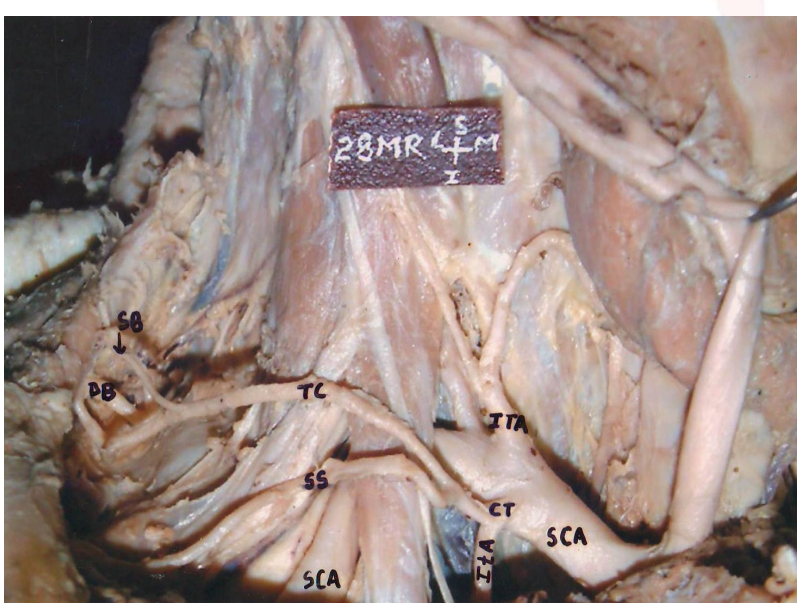

Int J Anat Res 2019, 7(2.2):6489-93. ISSN 2321-4287

\section{DISCUSSION}

Internal thoracic artery is the most commonly and appropriate term according to its localization and distribution in thorax. Initially, the artery was called "internal mammary artery" by Basle Nomina Anatomica in 1895 [15]' while later on official term was utilized the "internal thoracic artery" by Paris Nomina Anatomica in 1955 [16].

ItA was taking origin from $1^{\text {st }}$ part of subclavian artery either independently or in common with one or two branches of TT. Level of origin above the medial end of clavicle in our study was comparable as found in text books.

Different sites and modes of origin of this artery are compared with those described by earlier workers in Table No. 1

It is clear from Table No.1, that in majortiy of limbs (91.7\%) internal thoracic artery came directly from $1^{\text {st }}$ part of subclavian artery a finding in consonance with earlier workers $[3,18,20]$. Whereas no instance could be encountered of its origin directly from $2^{\text {nd }}$ or $3^{\text {rd }}$ part of subclavian artery, it was seen coming in common with suprascapular and superficial cervical, suprascapular and transverse cervical and with suprascapular from subclavain artery in $3.3 \%, 3.3 \%$ and $1.67 \%$ instances respectively. Earlier Rohlich [22] observed the internal thoracic artery arising in common with thyrocervical trunk or portions thereof in $6.2 \%$ of his dissections, a figure almost in consonance with our such incidence of $8.3 \%(3.3+3.3+1.67)$.

ItA always tend to arise opposite the root of thyrocervical trunk, but the cases in which there is common origin of ItA with branches of thyrocervical trunk, then its relation can be studied with inferior thyroid artery. Daseler and Anson emphasized that in cases TT is absent, one of its major branches usually the inferior thyroid artery occupies its usual site of origin [3].

Internal thoracic artery is often utilized as a graft for majority of CABG surgeries performed worldwide each year. Goldman mentioned that 10 year patency rate of ItA is $85 \%$ as compared to $61 \%$ for venous grafts [23]. The use of the internal thoracic artery (ItA) for myocardial revascularization in coronary artery disease increased 
because of its elastic properties resistant to atherosclerosis [24,25].

Common origin of other arteries together with the ItA which is being utilized as a CABG graft, may lead to symptomatic coronary steal phenomenon due to blood flow diversion. In these instances, graft may not be able to meet the myocardium oxygen demands and the need for re-operation may arise. So, during CABG surgery it is important to reassure the variant pattern of ItA to avoid complications like these. He reviewed the literature and suggests preoperative selective angiographic evaluation involving the SCA-ItA junction, except from the cases in which serious contraindications are present [26]. The risk of the procedure is not neglectable and some authors insist on its avoidance [27].

ItA is a suitable artery for free tissue transfer in reconstructive surgery of the thoracic region, especially in breast reconstruction because of its intrathoracic course and adequate size [14].

For breast reconstruction with free flaps, the vessels in the axilla are the most common recipient vessels. But after radiotherapy, these vessels tend to be small and vulnerable. Because the artery must be large enough and easily accessible for anastomoses, the ItA diameter is important in breast reconstruction [20]. Absence of a patent ItA and even variant course have the potential to limit its use in breast reconstructive surgeries [28].

According to Karaman et al [19], Diameters at the origin of the left and right internal thoracic arteries ranged from 1.4 to $3.7 \mathrm{~mm}$ (mean, 2.56 $\mathrm{mm}$ ) and 1.2 to $4.2 \mathrm{~mm}$ (mean 2.58 ) respectively and there was no gender difference. Similarly, in our studies average diameter of ItA at its origin was found to be $2.6 \mathrm{~mm}$ on left side and $2.8 \mathrm{~mm}$ on right side.

The close relationship of the ItAs with the phrenic nerves could explain some cases of paralysis of the diaphragm observed postoperatively in myocardial revascularization operations using the ItA $[29,30]$. Owne et al observed that there is no constant relationship between these two structures, and emphasize the need for caution when dissecting the internal mammary artery at or above the level of the first rib [29]. The area around origin of internal thoracic artery is commonly used in patients for percutaneous subclavian vein catheterization to determine central venous pressure and to administer drugs and solutions in emergency. It is also used in introducing a pacemaker. Internal thoracic artery is the main source of blood supply to sternum and any damage to this supply results in sternal wound complications $[31,32,33]$. So, one must aware of possible variations regarding it to prevent iatrogenic co mplications.

\section{CONCLUSION}

Although, ItA is the artery of choice in coronary artery bypass grafting and in breast reconstruction, we think surgeons must be aware of rarely seen variations which can influence surgical techniques, post-operative results and prognosis. Pre-operative angiography could be helpful as variant origin of ItA with one or other branch of TT could be undetected intraoperatively. This area is also used for interventional procedures, so knowledge of its variant anatomy is must to prevent iatrogenic complications.

\section{Conflicts of Interests: None}

\section{REFERENCES}

[1]. Romanes GJ. The blood vascular and lymphatics system. In: Cunningham's Text Book of Anatomy. $10^{\text {th }}$ ed. Oxford University Press London, New York, Toronto 1964; 882-885.

[2]. Williams PL, Bannister LH, Berry MM, Collins P, Dyson $\mathrm{M}$, Dussek JE et al. Cardiovascular system subclavian system of arteries, Gabella G Edr. In: Gray's Anatomy. 38 ${ }^{\text {th }}$ Edn, Churchill Livingstone, New York, London, 1995; 1529-1536.

[3]. Daseler EH and Anson BJ. Surgical anatomy of subclavian artery and its branches. Surg Gynaecol Obstet 1959; 108: 149-174.

[4]. Anson BJ. The cardiovascular system-Ateries and veins, Thomas M Oelrich edr. In: Morris Human Anatomy. $12^{\text {th }}$ Edn. The Blakiston Division McGraw Hill Book company, 1966; 613-858.

[5]. Yoshida K, Ohshima H, Murakami F, Tomida Y, Matsuura A, Hibi M, Kawamura M, Notoya A: Lateral origin of the right internal thoracic artery: report of a case. Surg Today 1997, 27(7):664-665.

[6]. Vorster W, Du Plooy PT, Meiring JH. Abnormal origin of internal thoracic and vertebral arteries. Clin Anat 1998; 11: 33-37.

[7]. Omar Y, Lachman N, Satyapal KS: Bilateral origin of the internal thoracic artery from the third part of the subclavian artery: A case report. Surg Radiol Anat 2001, 23:127-129. 
[8]. Krechowiecki A, Bohdan D, Wiechowski S. Variation of the internal thoracic artery. Folia Morphol (Warsz) 1973; 32(2): 173-184.

[9]. Puri N, Gupta, Mahant TS, Puri D: Bilateral internal thoracic artery harvesting; anatomical variations to be considered. Ind J Thorac Cardiovasc Surg 2007, 23:192-196.

[10]. Zeff RH, Kongtahworn C, Iannone LA, et al. Internal mammary artery versus saphenous vein graft to the left anterior descending coronary artery: prospective randomized study with 10-year follow-up. Ann Thorac Surg 1988;45:533-6.

[11]. Loop FD, Lytle BW, Cosgrove DM, Stewart RW, Goormastic M, Williams GW, Golding LA, Gill CC, Taylor PC, Sheldon WC, et al.: Influence of the internal-mammary-artery graft on 10-year survival and other cardiac events. N Engl J Med 1986, 314(1):16.

[12]. Cameron A, Davis KB, Green G, Schaff HV. Coronary bypass surgery with internal thoracic artery graftseffects on survival over a 15-year period. N Engl J Med 1996;334:216-9.

[13]. Henriquez-Pino JA, Gomes WJ, Prates JC, Buffolo E: Surgical anatomy of the internal thoracic artery. Ann Thorac Surg 1997, 64:1041-1045.

[14]. Hefel L, Schwabegger A, Ninkoviæ M, et al. Internal mammary vessels: anatomical and clinical considerations. Br J Plast Surg 1995;48:527-532.

[15].Basle Nomina Anatomica: Anatomische Nomenklatur. Verlag von Veit: Leipzig: von Wilhelm His; 1985.

[16].Paris Nomina Anatomica: Privately circulated, printed by Spottis-Woode. London: Ballatyne and Co; 1955.

[17]. Quain R. The anatomy of the arteries of Human body, 1844, 153-156. Cited by Cairney J. The anomalous right subclavian artery considered in the light of recent findings in arterial development: with a note on two cases of an unusual relation of the innominate artery to the trachea. J Anat 1924-1925; 59: 265-296.

[18]. Bean RB. A composite study of the subclavian artery in man. Am J Anat 1905; 4: 303-328.

[19]. DeGaris CF. Pattern of branches of subclavian artery in white and negros stocks. Am J Phys Anthropol 1924; VII: 95-106.

[20]. Karaman B, Battal B, Bozkurt Y, Bozlar U, Demirkol S, a ahin MA, Ta-ar M. The anatomic evaluation of the internal mammary artery using multidetector CT angiography. Diagn Interv Radiol 2012; 18:215-220.

[21]. Huelke DF. Variations in origin of branches of the axillary artery. Anat Rec 1958(b); 135: 35-41.

[22]. Rohlich K. Uber die arteria transversa colli des Menschen. Anat Anz 1934; 79: 27-53. Cited by Heulke DF. The dorsal scapular artery - A proposed term for artery to rhomboid muscles. Anat Rec 1962; 142: 57-61.
[23]. Goldman S, Zadina K, Moritz T, Ovitt T, Sethi G, Copeland JG, Thottapurathu L, Krasnicka B, Ellis N, Anderson RJ, Henderson W; VA Cooperative Study Group \#207/297/364. Long-term patency of saphenous vein and left internal mammary artery grafts after coronary artery bypass surgery: results from a Department of Veterans Affairs Cooperative Study. J Am Coll Cardiol. 2004; 44: 2149-2156.

[24]. Barry MM, Foulon P, Touati G, Ledoux B, Sevestre H, Carmi D, Laude M: Comparative histological and biometric study of the coronary, radial and left internal thoracic arteries. Surg Radiol Anat 2003, 25(3-4):284-289.

[25]. Marx R, Clahsen H, Schneider R, Sons H, Klein RM, Gülker $\mathrm{H}$ : Histomorphological studies of the distal internal thoracic artery which support its use for coronary artery bypass grafting. Atherosclerosis. 2001 Nov;159(1):43-8.

[26]. Parkasaves G, Natsis K, Tzika M, loannidis O and Kitsoulis P. Abnormal origin of internal thoracic artery from the thyrocervical trunk: surgical considerations. Journal of Cardiothoracic Surgery 2012, 7:63

[27]. Tartini R, Steinbrunn W, Kappenberger L, Goebel N, Turina M. Anomalous origin of the left thyrocervical trunk as a cause of residual pain after myocardial revascularization with internal mammary artery. Ann Thorac Surg 1985, 40(3):302-304.

[28]. Murray AC, Rozen WM, Alonso-Burgos A, Ashton MW, Garcia-Tutor E, Whitaker IS. The anatomy and variations of the internal thoracic (internal mammary) artery and implications in autologous breast reconstruction: clinical anatomical study and literature review. Surg Radiol Anat. 2012 Mar;34(2):159-65.

[29]. Owens WA, Gladstone DJ, Heylings DJ. Surgical anatomy of the phrenic nerve and internal mammary artery. Ann Thorac Surg 1994;58:843-4.

[30]. Deng Y, Byth K, Paterson HS. Phrenic nerve injury associated with high free right internal mammary artery harvesting. Ann Thorac Surg. 2003 Aug;76(2):459-63.

[31]. Hazelrigg SR, Wellons HA, Schneider JA et al. Wound complication after median sternotomy. J Thorac and Cardiovasc Surg 1989; 98: 1096-1099.

[32]. Loop FD, Lytle BW, Cosgrove DM, Mahfood S, McHenry MC, Goormastic M et al. Sternal wound complication after isolated CABG: Early and late mortality, morbidity and cost of care. Ann Thoracic Surg 1990; 49: 179-187.

[33]. Carrier M, Gregoire J, Tronc F. Effect of internal mammary artery dissection on sternal vascularisation. Ann of Thoracic Surg 1992; 53: 115-119. 